\title{
Data for Radon-222 and Other Radionuclides In Ground Water, Nevada, 1986-89
}

By Michael S. Lico

U.S. GEOLOGICAL SURVEY

Open-File Report 91-488

Prepared in cooperation with the

NEVADA BUREAU OF MINES AND GEOLOGY and the NEVADA BUREAU OF CONSUMER HEALTH PROTECTION SERVICES

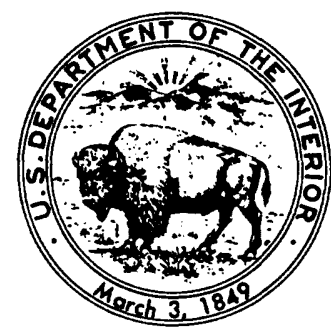

Carson City, Nevada 1992 


\title{
U.S. DEPARTMENT OF THE INTERIOR
}

MANUEL LUJAN, JR., Secretary

\section{U.S. GEOLOGICAL SURVEY}

Dallas L. Peck, Director

\begin{abstract}
Any use of trade, product, or firm names in this publication is for descriptive purposes only and does not constitule endorsement by the U.S. Government.
\end{abstract}

For additional information write to:

U.S. Geological Survey Room 227 Federal Building 705 North Plaza Street Carson City, NV 89701
Copies of this report may be purchased from:

U.S. Geological Survey

Books and Open-File Reports Section Federal Center

Box 25425

Denver, CO 80225 
Abstract

Introduction . . . . . . . . . . . . . . . . . . . . . . . . . . 1

Purpose and scope . . . . . . . . . . . . . . . . . . . . . . . 2

Methods of sample collection and analysis . . . . . . . . . . 2

Radionuclide data . . . . . . . . . . . . . . . . . . . . . . 4

References cited . . . . . . . . . . . . . . . . . . . . . 17

\title{
IIIUSTRATIONS
}

(plate is in pocket at back of report)

Plate 1. Map showing location of ground-water sites in

the Carson, Truckee, and Walker River basins, northwestern Nevada, where water samples were collected and analyzed for radioactive constituents

Figure 1. Map showing location of areas in figures 2-4

and plate 1 and hydrographic areas in Nevada . . . . . 3

2-4. Maps showing location of sampling sites:

2. Smoke Creek Desert hydrographic area . . . . . . 5

3. Marys Creek hydrographic area . . . . . . . . . 6

4. Amargosa Desert hydrographic area . . . . . . . 7

\section{TABLES}

Table 1. Statistical summary of radon-222 activities in groundwater samples collected in Nevada, 1986-89... . . .

2. Radionuclide analyses and other information for wells and springs sampled in parts of Nevada, 1986-89 . .

\section{ABBREVIATED WATER-QUALITY UNITS USED IN THIS REPORT}

\author{
L (liter) \\ $\mu \mathrm{g} / \mathrm{L}$ (micrograms per liter) \\ $\mu \mathrm{m}$ (micrometer) \\ $\mathrm{mg} / \mathrm{L}$ (milligrams per liter) \\ mL (milliliter) \\ $\mathrm{pCi} / \mathrm{L}$ (picocuries per liter)
}




\title{
DATA FOR RADON-222 AND OTHER RADIONUCLIDES IN GROUND WATER, NEVADA, 1986-89
}

\author{
By Michael S. Lico
}

\begin{abstract}
ABSTRACI
The U.S. Geological Survey collected an extensive amount of radionuclide data from ground water in many parts of Nevada during 1986-89. Data presented in this report include a statistical summary of all radon-222 data in the U.S. Geological Survey NWIS data base, location and other information on the 278 wells and springs sampled, and results of chemical analyses that include radon-222 activity, gross alpha and gross beta radioactivity, radium- 226 activity, and uranium concentrations. Maps are provided to show locations of sampled wells and springs.
\end{abstract}

\section{INTRODUCTION}

Radon is a naturally occurring, colorless, odorless, inert gas formed by the radioactive decay of uranium-238 (Wanty and Schoen, 1991). Uranium-238 is present in trace concentrations in all rocks, but certain types--such as granitic rocks, late-stage volcanic rocks, shales, and limestones--generally contain the highest concentrations (Lanctot and others, 1985, p. 68).

Radon and its decay products are radioactive and, if present at sufficient activities in air, can cause lung cancer in humans (Cothern, 1987, p. 7). Radon released to air from drinking-water sources has been estimated to cause as much as 7 percent of the 5,000 to 20,000 lung-cancer fatalities per year in the United States (Cothern and others, 1986 , p. 40). Radon gas can be released from water to the atmosphere by any one of several household activities, including showering and laundering (Lowry and others, 1987, p. 363). Human exposure to radon and its radioactive decay products occurs primarily in two ways:

(1) inhalation of radon gas or decay products that have adhered to small dust particles, directly affecting the lungs, and (2) ingestion of radon-containing water, increasing the net dose of radiation to the stomach and intestines (Brutsaert and others, 1981, p. 407). Potential health effects are greatest to private domestic well-water users because of the generally short time between pumping and consumption of well water. The half-life of radon is relatively short ( 3.82 days); thus, long storage times in supply tanks and aeration with subsequent loss of radon to the atmosphere can greatly decrease the amount of radon in the well water by the time of actual use. 
Recent increases in the population of Nevada have resulted in the construction of many new private and municipal wells for domestic water supplies. Many of these new wells are constructed in areas where previous studies indicate high activities of radon may exist. However, little is known about the distribution and occurrence of radon (specifically radon-222) in ground water of Nevada and further study is needed to determine the extent of high radon activities. Otton and others (1985, p. 21) found anomalously high activities of radon (as much as $345 \mathrm{pCi} / \mathrm{L}$ ) in water from springs in the Lake Tahoe basin. A study of public drinking-water supplies (Horton, 1985, p. 123) found high activities of radon in the Gardnerville $(724 \mathrm{pCi} / \mathrm{L})$, $\operatorname{Reno}(1,104 \mathrm{pCi} / \mathrm{L})$, and Yerington $(1,348 \mathrm{pCi} / \mathrm{L})$ areas (fig.1).

\section{Purpose and Scope}

The purpose of this report is to release data collected by the U.S. Geological Survey from 1986 through 1989, in cooperation with the Nevada Bureau of Mines and Geology and the Nevada Bureau of Consumer Health Protection Services. Data included in this report are all analyses for radon-222 activity, gross alpha radioactivity, gross beta radioactivity, radium-226 activity, and uranium concentrations in ground-water samples. Most of the data are from northern Nevada, but data from three sites in the Amargosa Desert also are included. The 278 sample-collection sites are shown in figures 2 through 4 and on plate 1 .

\section{Methods of Sample Collection and Analysis}

Water samples were obtained at each well by pumping or bailing until water temperature, specific conductance, and pH were constant, and a minimum of three well-bore volumes of water was extracted. Existing in-well pumps were used to sample public-supply and domestic wells. Samples were collected as near to the well as possible, and in all cases samples were taken before the water entered a pressure tank. Observation wells were sampled using a positive-displacement bladder pump or a Teflon bailer. Samples were collected from a polyethylene tube fitted to the pump discharge, or they were taken directly from the bailer.

Samples obtained from springs were collected as close as possible to the orifice using a syringe or a peristaltic pump.

Water samples for gross alpha and beta, radium, and uranium analysis were filtered through a 0.45-micrometer nitrocellulose membrane into 1-liter, acid-cleaned, polyethylene bottles and acidified to a $\mathrm{pH}$ of about 1 with concentrated hydrochloric acid (Thatcher and others, 1977, p. 11).

Gross alpha and beta radioactivity were determined by evaporating an aliquot of sample and counting the emitted alpha and beta radiation. The measured radiation was compared to the radiation emitted by standard materials--natural uranium in the case of alpha and an equilibrium mixture of strontium-90/yttrium-90 for beta. A detailed description of this analytical method is given by Thatcher and others (1977, p. 29-32). This method is regarded as a semiquantitative measure of gross sample activity. 


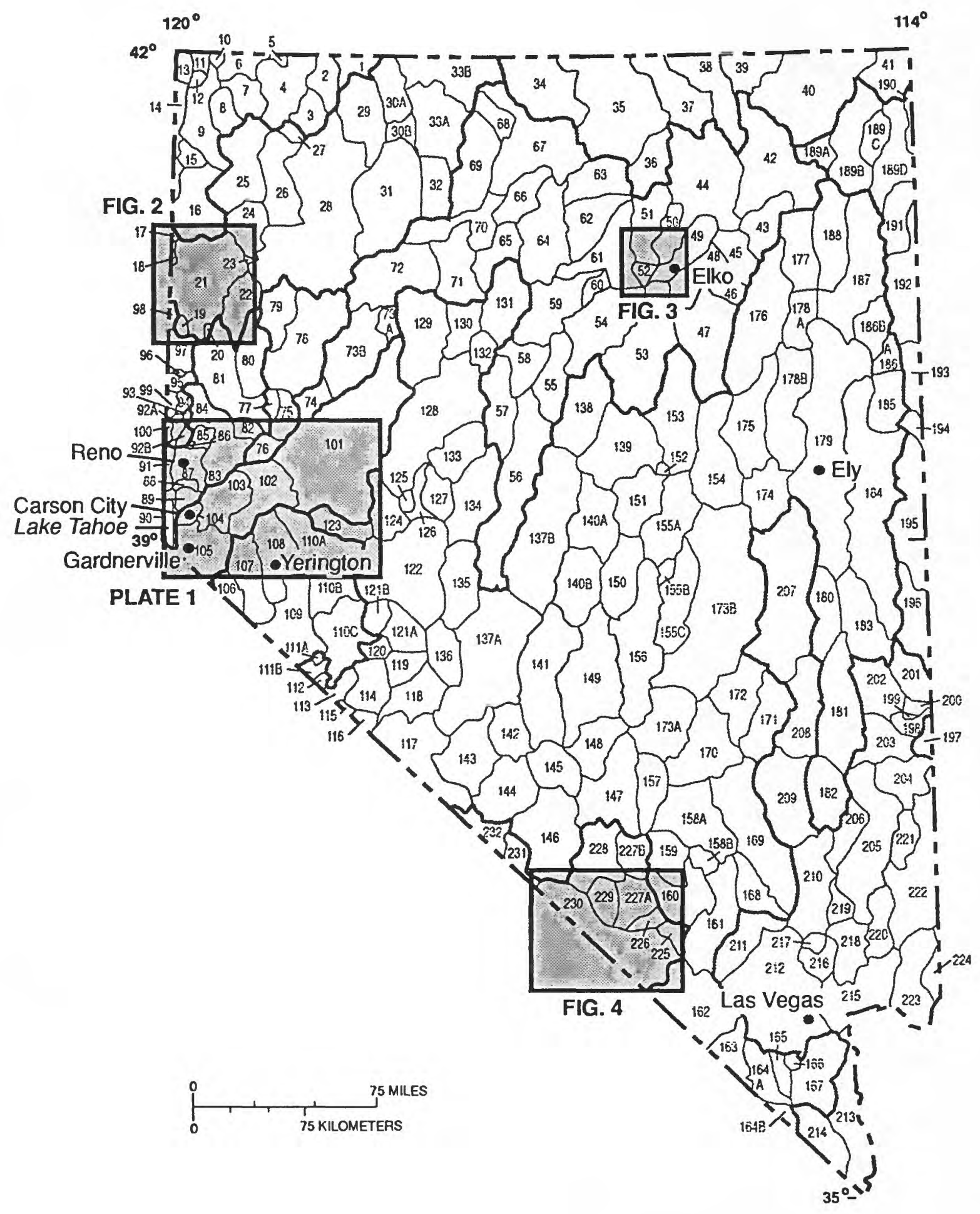

FIGURE 1.--Location of areas shown in figures 2 through 4 and plate 1 (this report) and hydrographic areas in Nevada. Modified from Rush (1968). Names and numbers of hydrographic areas where radon samples were collected are listed in table 1. 
Radium-226 activity was determined by coprecipitating radium with barium sulfate, centrifuging to collect the precipitate, dissolving the precipitate in an alkaline sodium diethylene triamine pentacetate solution, allowing time for the ingrowth of alpha-emitting daughters, and counting the alpha activity (Thatcher and others, 1977, p. 43-49).

Dissolved uranium concentration was determined by evaporating an aliquot of sample, fusing the residue with a flux of sodium fluoride, sodium carbonate, and potassium carbonate, and allowing the residue-flux mixture to dry into a small disk. If a sample contained more than $10,000 \mathrm{mg} / \mathrm{L}$ of dissolved solids, a different procedure was followed: The uranium was first purified prior to evaporation by coprecipitation on aluminum phosphate, dissolving the precipitate in dilute nitric acid, and extracting the uranium with ethyl ether in the presence of magnesium nitrate. The fluorescence of the disk under ultraviolet light was measured in a reflection-type fluorimeter (Thatcher and others, 1977, p. 83-92).

Samples for laboratory analysis of total radon activity were obtained by bottom filling a $500 \mathrm{~mL}$ plastic beaker and allowing several beaker volumes of water to overflow, withdrawing a 10-mL aliquot of sample with a syringe from near the bottom of the beaker, carefully injecting the aliquot beneath $10 \mathrm{~mL}$ of a mineral-oil-based scintillator contained in a $30-\mathrm{mL}$ glass scintillation vial, and tightly capping and shaking the vial. The vials were then shipped by express mail to the U.S. Geological Survey laboratory in Arvada, Colo., for analysis by liquid-scintillation counting (Prichard and Gesell, 1977). Samples were shipped as soon as possible after collection (within 24 hours) to minimize radon decay prior to analysis.

Dissolved-radon concentrations were also measured, using a fieldscreening method. A 1 -liter polyethylene bottle was filled with $750 \mathrm{~mL}$ of water and capped with a septum cap. The bottle was shaken vigorously for 30 seconds to evolve radon gas in solution, then allowed to settle for 3 minutes. A $50-\mathrm{mL}$ sample of the head-space gas was removed through the septum cap with a syringe and needle. The gas sample was injected, through a septum connector, into an evacuated Lucas-type, phosphorcoated cell. The cell was inserted into an EDA-200 alpha-scintillometer and the gas activity counted for 30 minutes. The counts were converted to radon activities, in $\mathrm{pCi} / \mathrm{L}$.

Duplicate water samples were collected from each well for radon analysis. If the duplicate analyses agreed to within 5 percent, the average of the two analyses was used; if not, the larger value was used. Loss of radon gas due to aeration during pumping may be significant for samples from public-supply wells, so these analyses probably represent lower radon activities at the wellhead than in the undisturbed aquifer.

\section{RADIONUCLIDE DATA}

A statistical summary of all radon-222 analyses of ground-water samples collected by the U.S. Geological Survey in Nevada during 1986-89 is presented in table 1. This table lists statistics for radon-222 activities in the entire state as well as for selected hydrographic areas. Table 2 contains all data collected for radon-222, gross alpha and gross beta radioactivity, radium-226, and uranium, and other information for the 278 wells and springs sampled during 1986-89. 


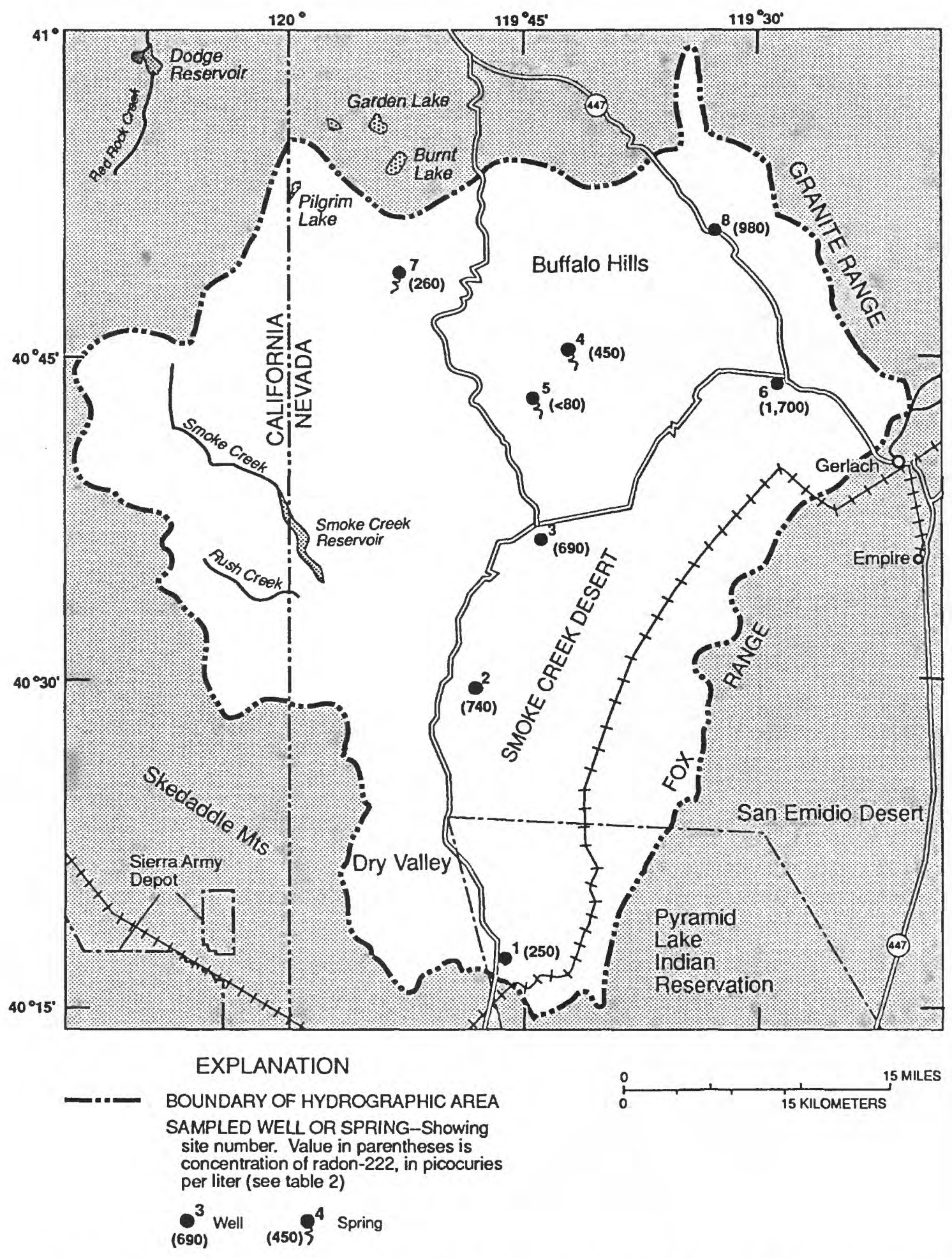

FIGURE 2.--Location of sampling sites in the Smoke Creek Desert hydrographic area. 


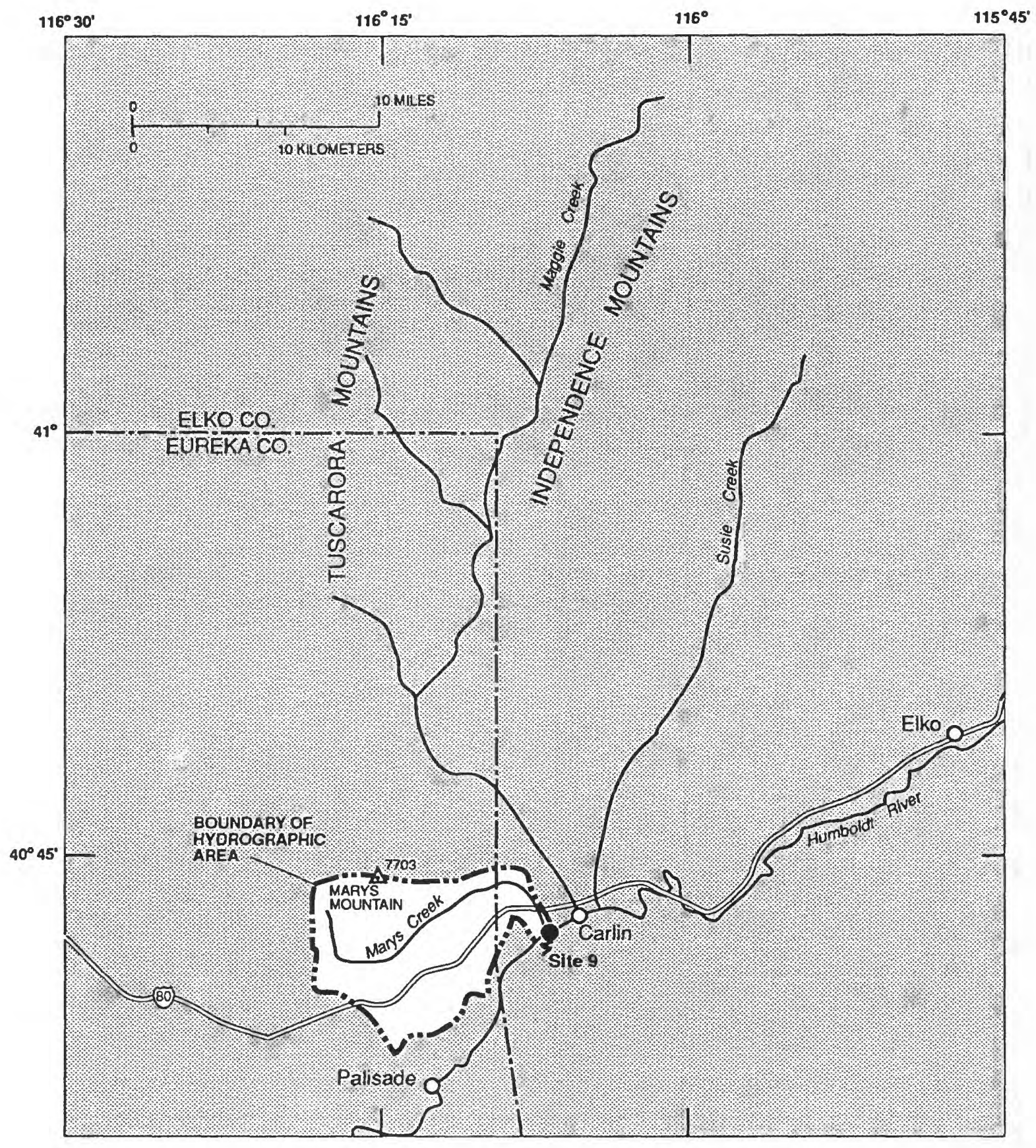

FIGURE 3.--Location of spring-sampling site in the Marys Creek hydrographic area. Concentration of radon-222 was 530 picocuries per liter. 


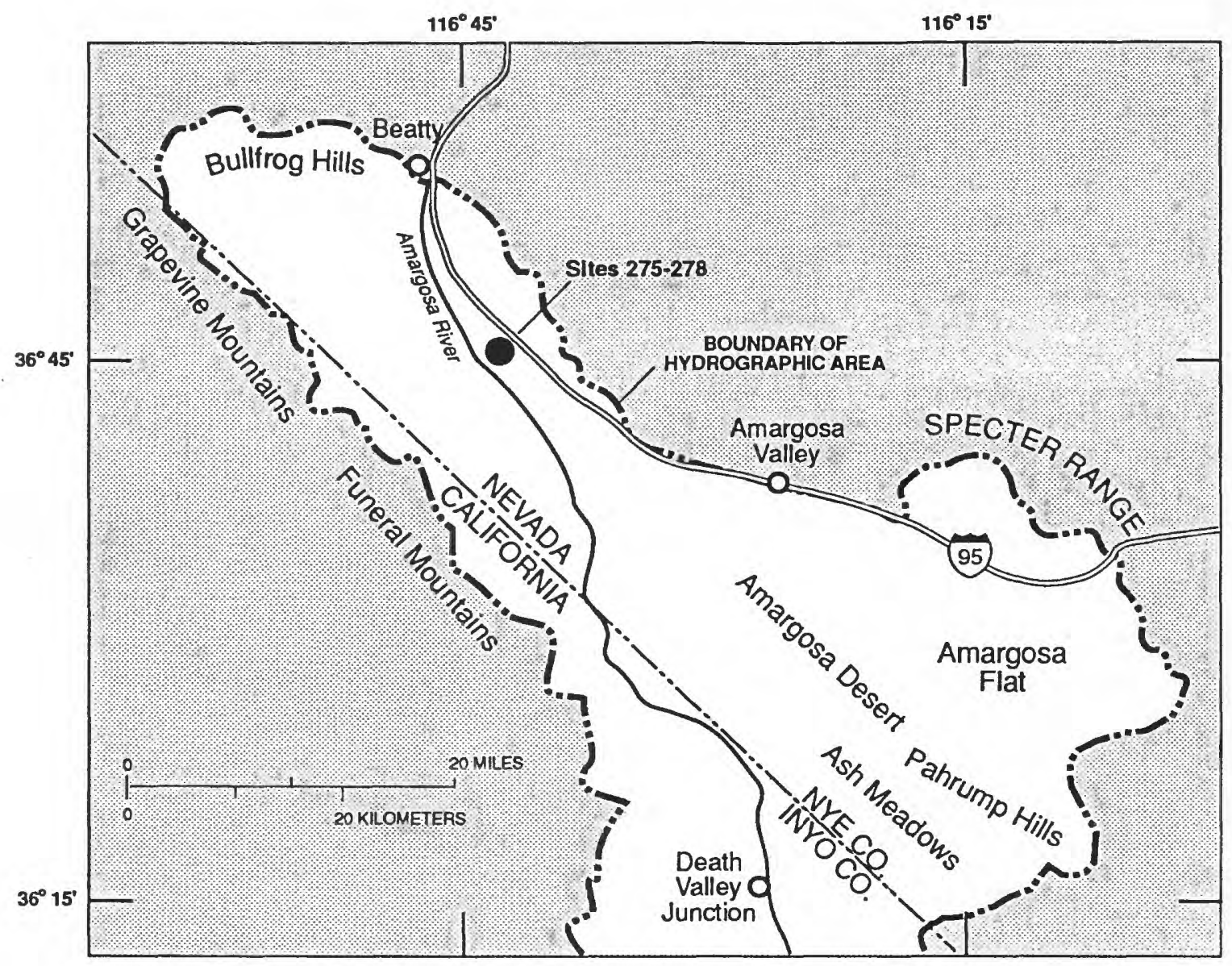

FIGURE 4.--Location of well-sampling sites in the Amargosa Desert hydrographic area. Concentrations of radon-222 at sites 275-278 ranged from 320 to 460 picocuries per liter. 
TABIE 1.--Statietical eummary of radon-222 activities in ground-water eamples collected in Nevada, 1986-89

[Radon-222 activities are in picocuries per liter; "<," activity is less than the indicated value; "--," statistical parameters not computed for fewer than elght sites.]

\begin{tabular}{|c|c|c|c|c|c|c|c|c|}
\hline \multirow{2}{*}{$\begin{array}{l}\text { Hydrographic } \\
\text { area/number } \\
\text { (flgure 1) }\end{array}$} & \multirow{2}{*}{$\begin{array}{l}\text { Number } \\
\text { of } \\
\text { sites }\end{array}$} & \multirow{2}{*}{$\begin{array}{l}\text { Arith- } \\
\text { metic } \\
\text { mean }\end{array}$} & \multirow[b]{2}{*}{ Median } & \multirow{2}{*}{$\begin{array}{l}\text { Stand- } \\
\text { ard } \\
\text { devia- } \\
\text { tion }\end{array}$} & \multirow[b]{2}{*}{$\begin{array}{l}\text { Mini- } \\
\text { mum }\end{array}$} & \multirow[b]{2}{*}{$\begin{array}{l}\text { Maxi- } \\
\text { mum }\end{array}$} & \multicolumn{2}{|c|}{ Percentiles } \\
\hline & & & & & & & $25^{t h}$ & $75^{t h}$ \\
\hline $\begin{array}{l}\text { Smoke Creek Desert/21 } \\
\text { Marys Creek Area/52 } \\
\text { Fernley Area/76 } \\
\text { Spanish Springs V./85 }\end{array}$ & $\begin{array}{l}8 \\
1 \\
3 \\
3\end{array}$ & $\begin{array}{c}640 \\
-- \\
--\end{array}$ & $\begin{array}{r}570 \\
-- \\
-- \\
--\end{array}$ & $\begin{array}{r}525 \\
-- \\
--\end{array}$ & $\begin{array}{l}<80 \\
530 \\
<80 \\
420\end{array}$ & $\begin{array}{r}1,700 \\
530 \\
720 \\
880\end{array}$ & $\begin{array}{r}252 \\
-- \\
--\end{array}$ & $\begin{array}{r}920 \\
--- \\
--\end{array}$ \\
\hline $\begin{array}{l}\text { Truckee Meadows } / 87 \\
\text { Pleasant Valley/88 } \\
\text { Washoe Valley/89 } \\
\text { Lake Tahoe Basin/90 }\end{array}$ & $\begin{array}{r}12 \\
3 \\
4 \\
25\end{array}$ & $\begin{array}{r}780 \\
-- \\
4,188\end{array}$ & $\begin{array}{r}750 \\
--- \\
2,500\end{array}$ & $\begin{array}{r}192 \\
-- \\
4,377\end{array}$ & $\begin{array}{r}560 \\
800 \\
500 \\
<100\end{array}$ & $\begin{array}{r}1,200 \\
4,100 \\
12,000 \\
16,000\end{array}$ & $\begin{array}{r}635 \\
-- \\
\overline{--}\end{array}$ & $\begin{array}{r}878 \\
-- \\
8,400\end{array}$ \\
\hline $\begin{array}{l}\text { Lemmon Valley/92 } \\
\text { Carson Desert } / 101 \\
\text { Churchill Valley/102 } \\
\text { Dayton Valley/103 }\end{array}$ & $\begin{array}{l}1 \\
70 \\
10 \\
23\end{array}$ & $\begin{array}{l}-- \\
659 \\
529 \\
726\end{array}$ & $\begin{array}{l}-- \\
555 \\
470 \\
750\end{array}$ & $\begin{array}{l}-- \\
387 \\
294 \\
366\end{array}$ & $\begin{array}{l}640 \\
<80 \\
160 \\
190\end{array}$ & $\begin{array}{r}640 \\
2,200 \\
1,000 \\
1,800\end{array}$ & $\begin{array}{l}-- \\
400 \\
300 \\
430\end{array}$ & $\begin{array}{l}-\overline{-} \\
852 \\
852 \\
970\end{array}$ \\
\hline $\begin{array}{l}\text { Eagle Valley/104 } \\
\text { Carson Valley/105 } \\
\text { Antelope Valley/106 } \\
\text { Amargosa Desert } / 230\end{array}$ & $\begin{array}{r}54 \\
54 \\
3 \\
4\end{array}$ & $\begin{array}{r}2,780 \\
1,171 \\
-- \\
--\end{array}$ & $\begin{array}{r}2,050 \\
730 \\
-- \\
--\end{array}$ & $\begin{array}{r}2,886 \\
1,764 \\
-- \\
--\end{array}$ & $\begin{array}{l}<80 \\
<80 \\
300 \\
320\end{array}$ & $\begin{array}{r}14,000 \\
14,000 \\
1,400 \\
460\end{array}$ & $\begin{array}{c}1,200 \\
495 \\
-- \\
--\end{array}$ & $\begin{array}{c}3,125 \\
1,100 \\
-- \\
--\end{array}$ \\
\hline All sites & 278 & 1,556 & 766 & 2,388 & $<80$ & 16,000 & 487 & 1,400 \\
\hline
\end{tabular}




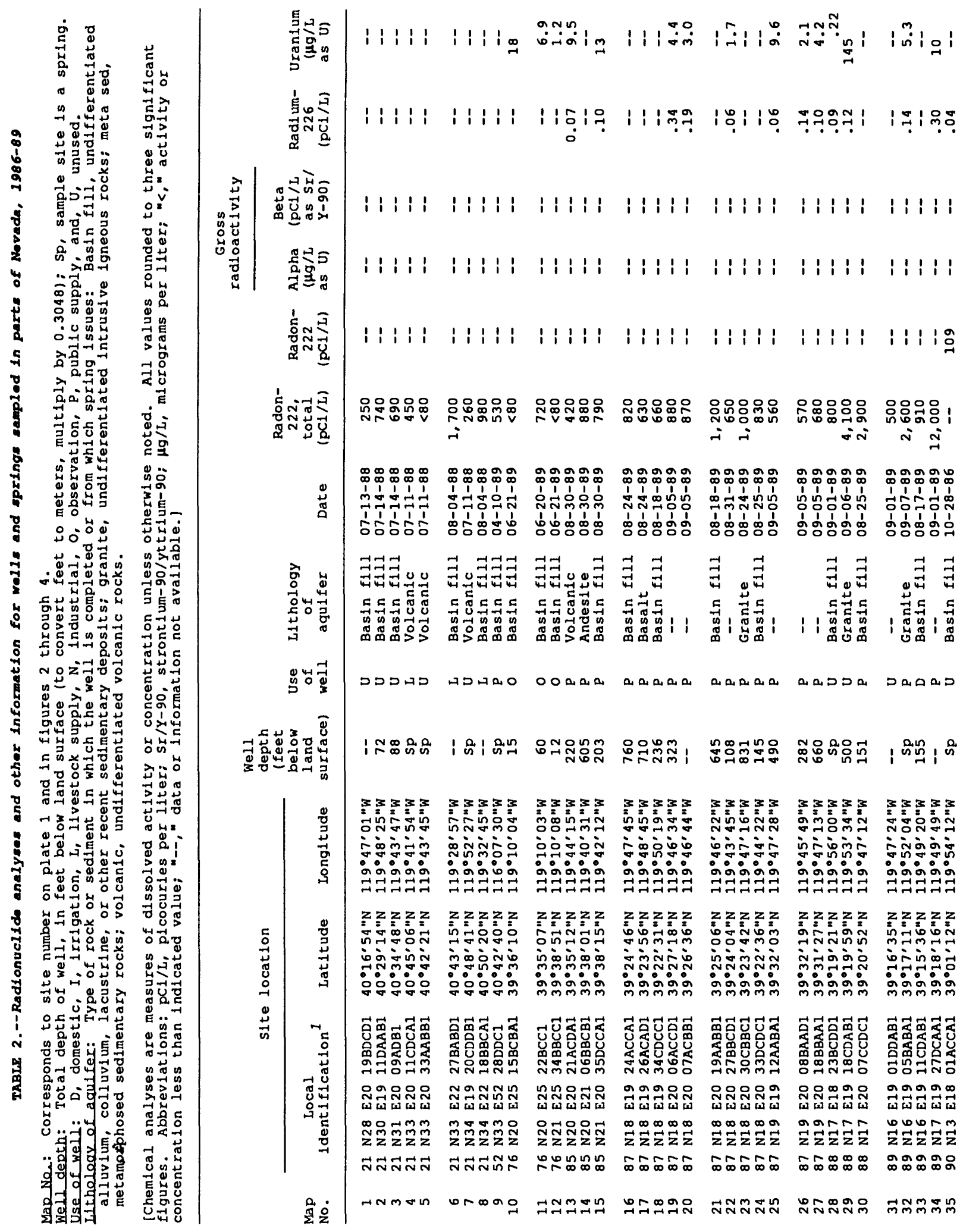




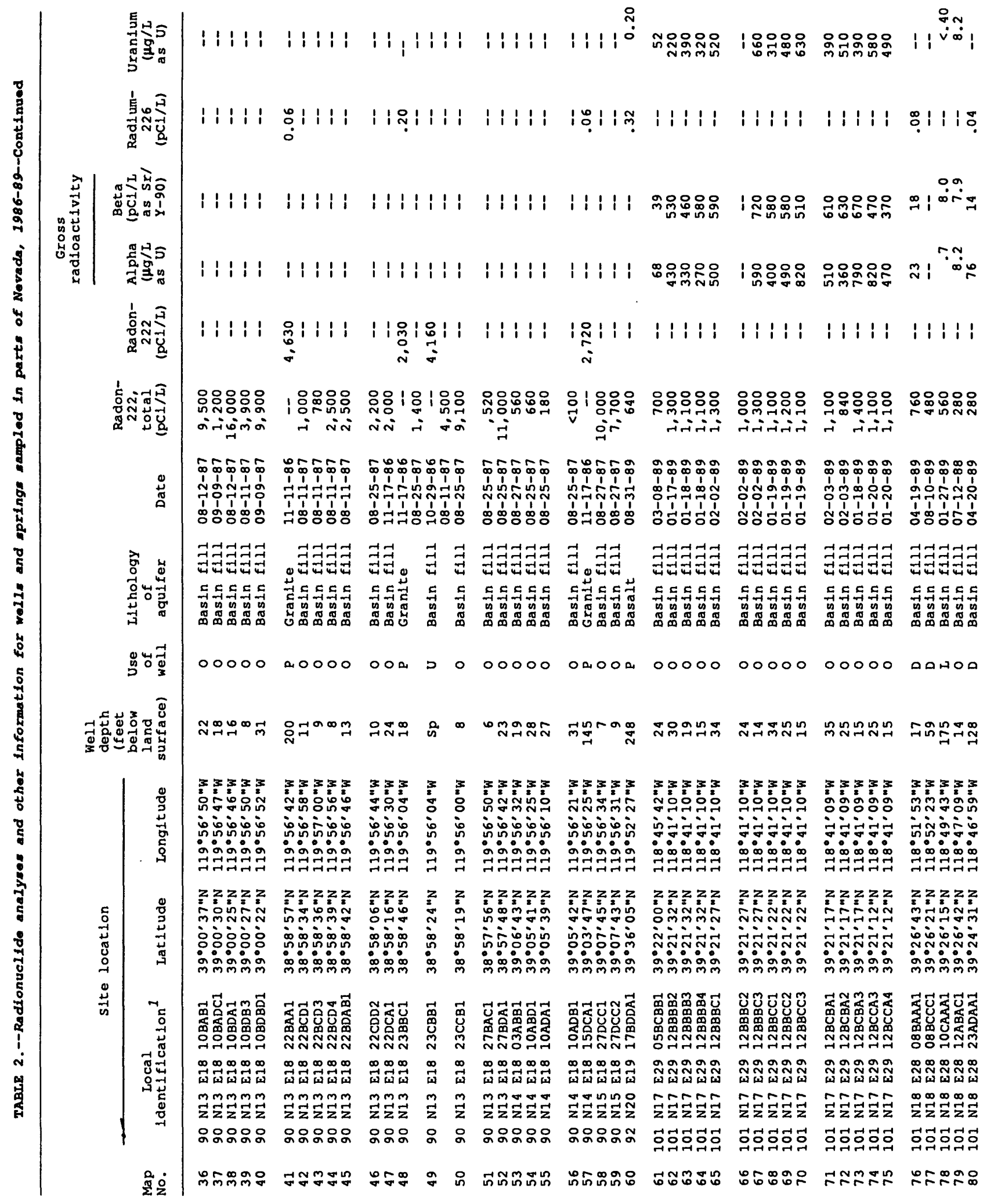




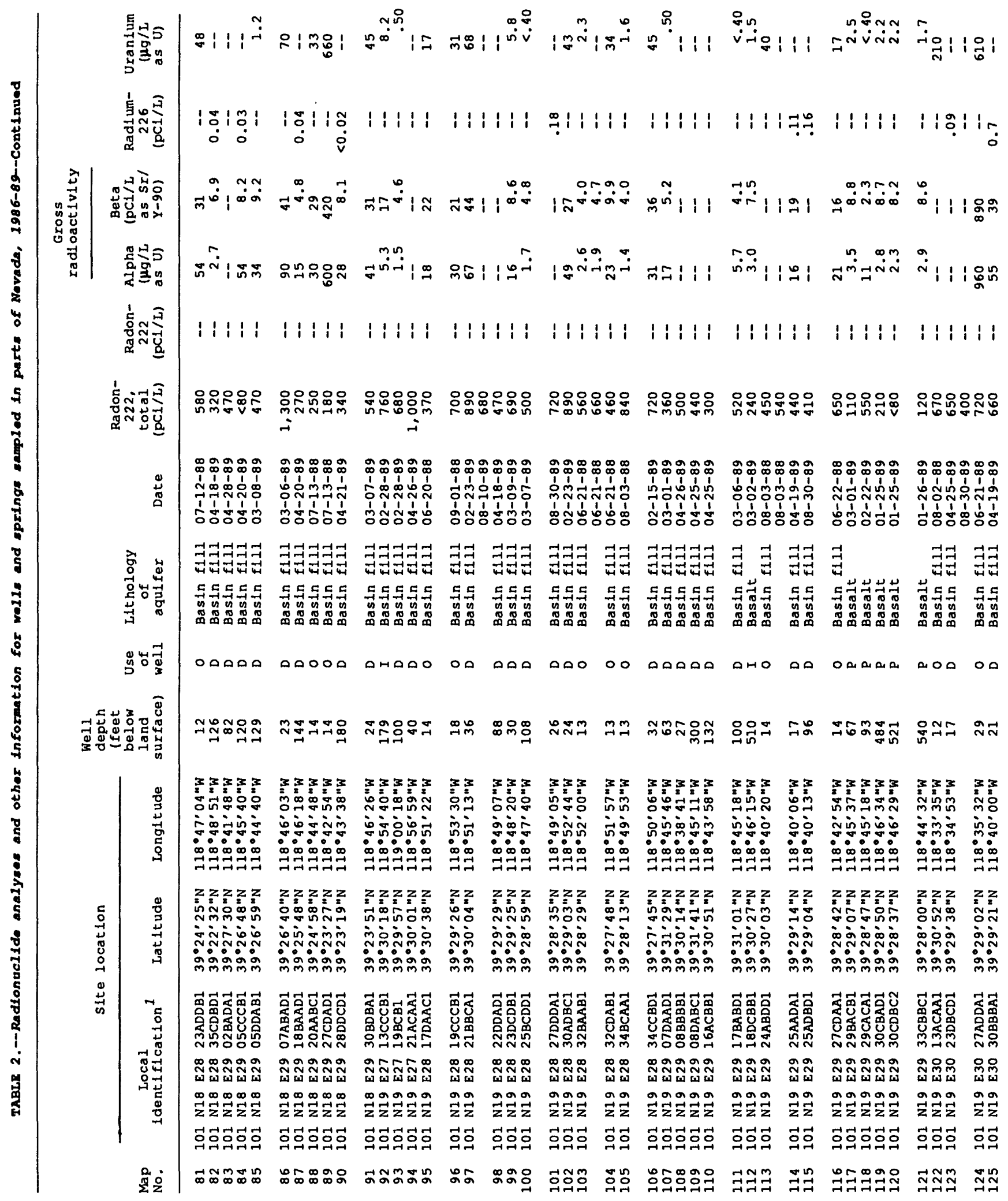




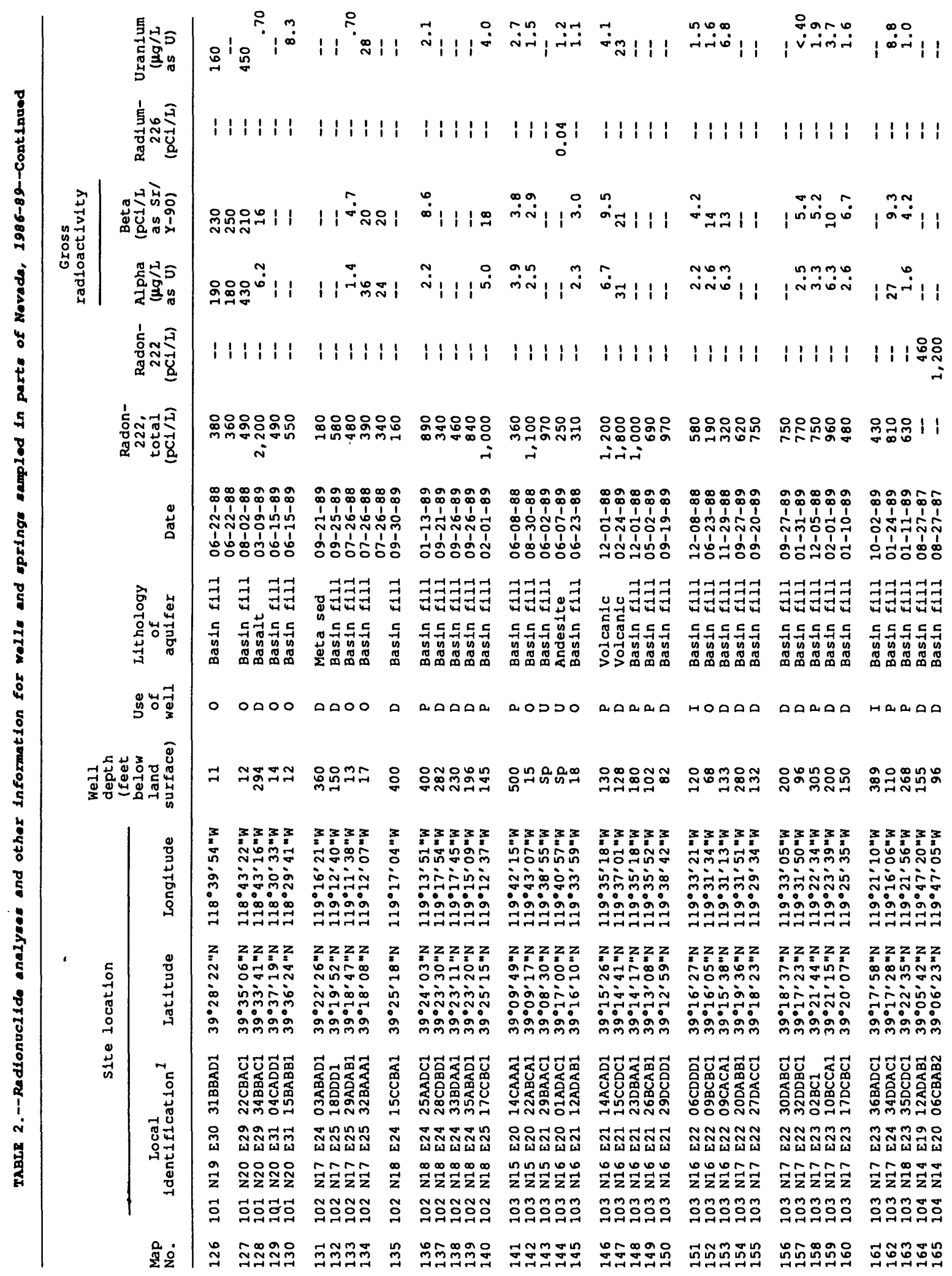




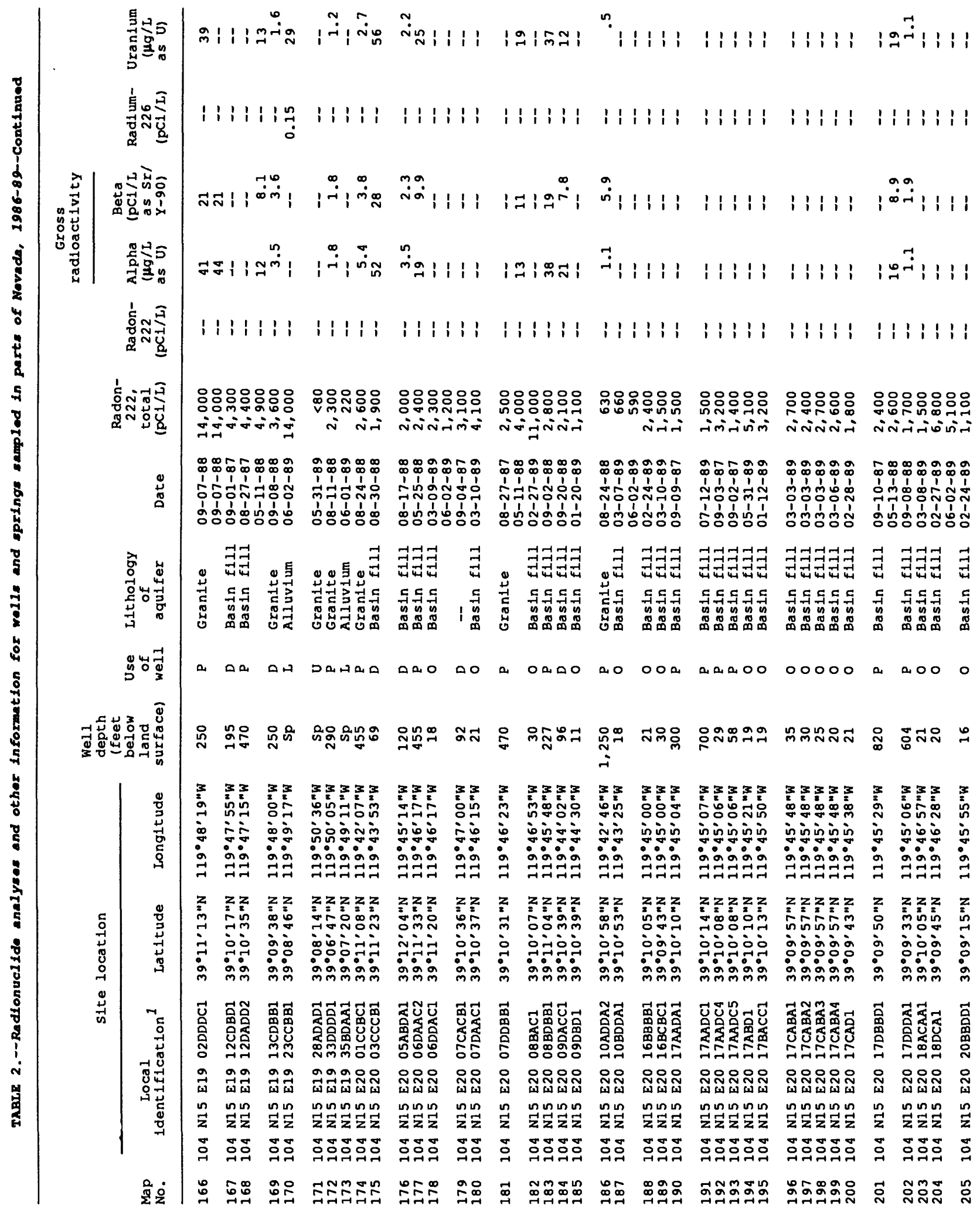




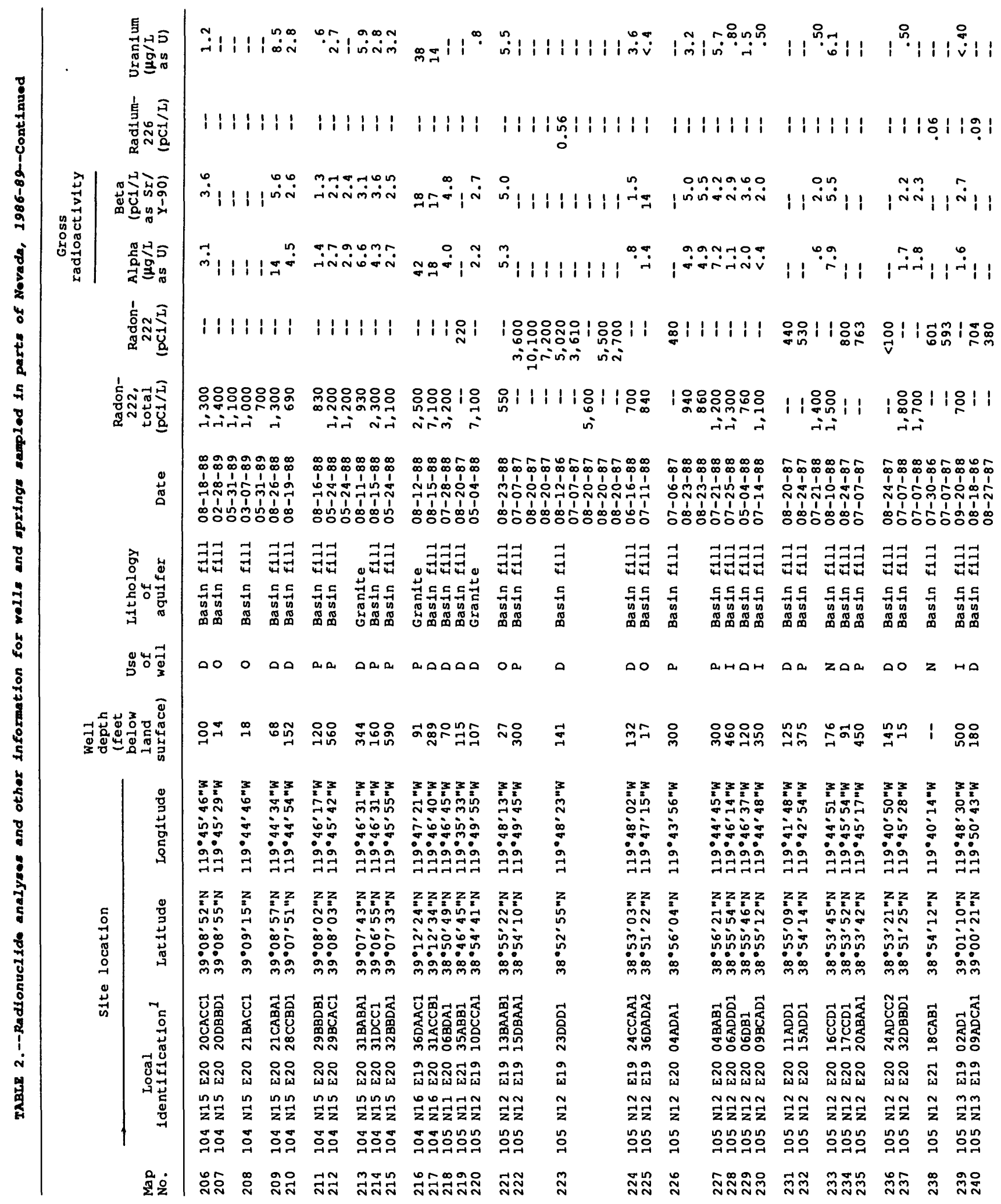




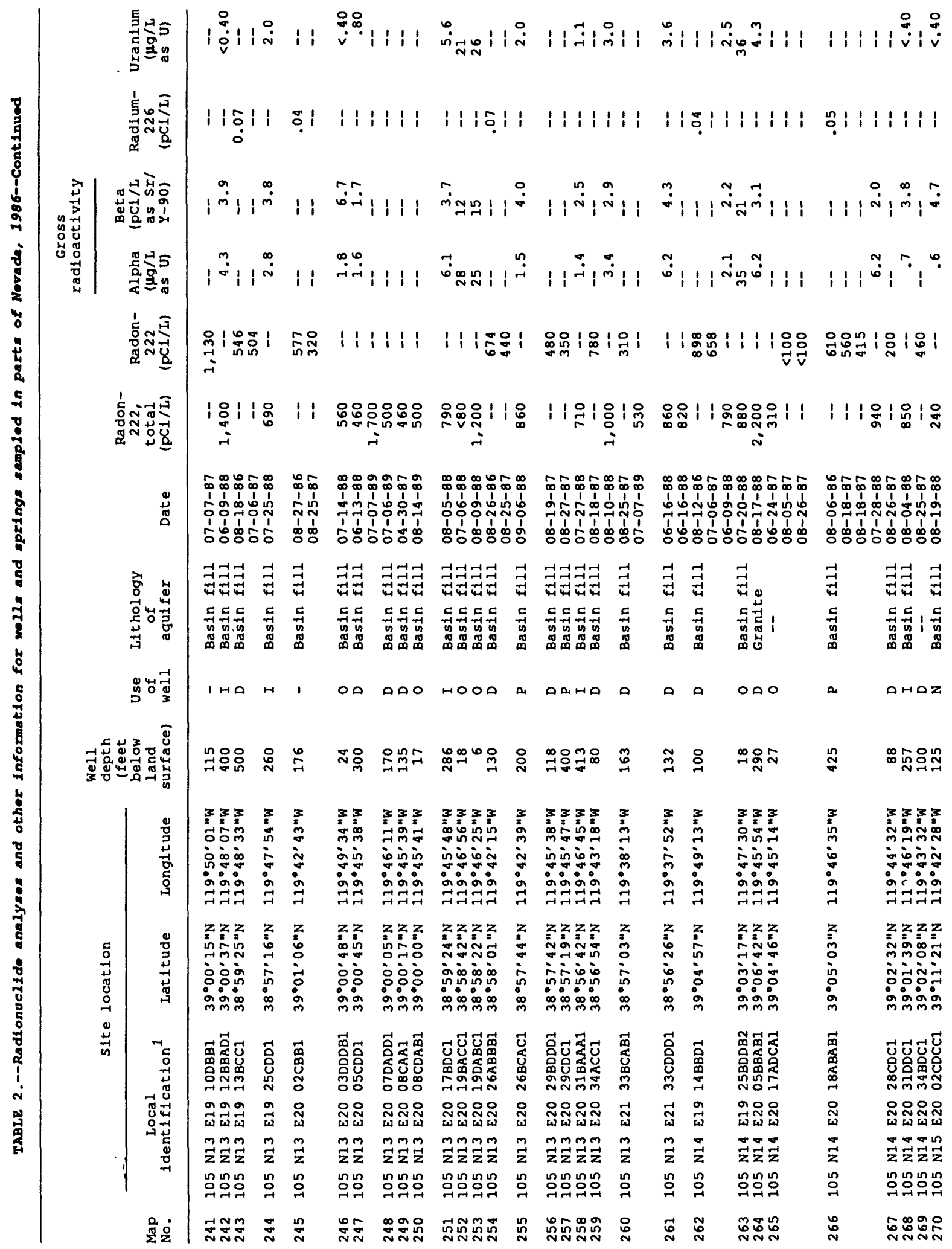




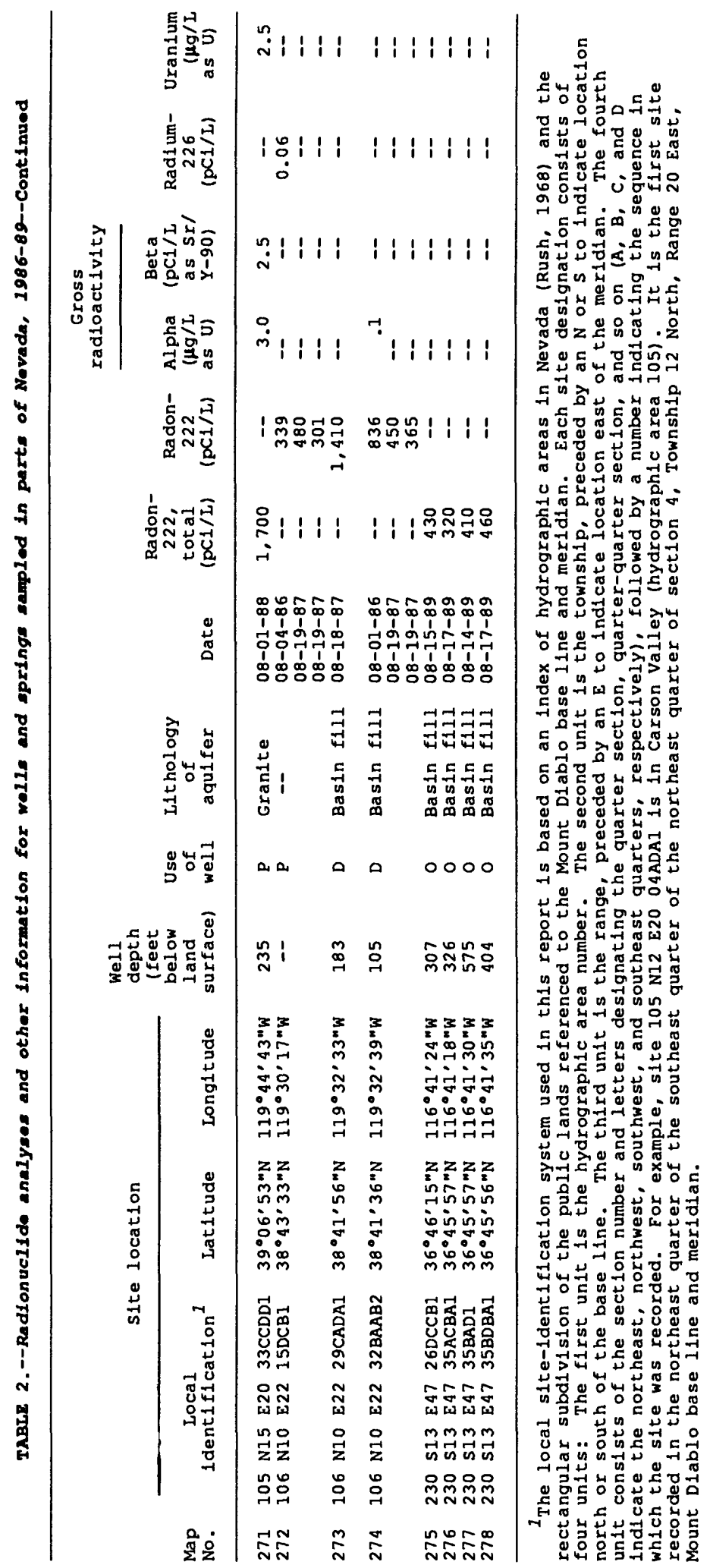




\section{REFERENCES CITED}

Brutsaert, W.F., Norton, S.A., Hess, C.T., and Williams, J.S., 1981, Geologic and hydrologic factors controlling radon-222 in ground water in Maine: Ground Water, v. 19, no. 4, p. 407-417.

Cothern, C.R., 1987, Development of regulations for radionuclides in drinking water, in Graves, Barbara, ed., Radon, radium, and other radioactivity in ground water: Chelsea, Mich., Lewis Publishers, p. 1-11.

Cothern, C.R., Lappenbusch, W.L., and Michel, Jacqueline, 1986, Drinking-water contribution to natural background radiation: Health Physics, v. 50, p. 33-47.

Horton, T.R., 1985, Nationwide occurrence of radon and other natural radioactivity in public water supplies: U.S. Environmental Protection Agency report 520/5-85-008, 208 p.

Lanctot, E.M., Tolman, A.I., and Loiselle, Marc, 1985, Hydrogeochemistry of radon in ground water: Eastern Regional Ground Water

Conference, Association of Ground Water Scientists and Engineers, National Water Well Association, Portland, Maine, July 1985 , Proceedings, p. 66-85.

Lowry, J.D., Hoxie, D.C., and Moreau, Eugene, 1987, Extreme levels of Rn and $U$ in a private water supply, in Graves, Barbara, ed., Radon, radium, and other radioactivity in ground water: Chelsea, Mich., Lewis Publishers, p. 363-375.

Otton, J.K., Zielinski, R.A., and Been, J.M., 1985, Uranium in Holocene valley-fill sediments, and uranium, radon, and helium in waters, Lake Tahoe-Carson Range area, Nevada and California: U.S. Geological Survey Open-File Report 85-389, $30 \mathrm{p}$.

Prichard, H.M., and Gesell, T.F., 1977, Rapid measurements of Rn concentrations in water with a commercial liquid scintillation counter: Health Physics, v. 33, p. 577-581.

Rush, F.E., 1968, Index of hydrographic areas in Nevada: Nevada Division of Water Resources, Information Report 6, 38 p.

Thatcher, L.L., Janzer, V.J., and Edwards, K.W., 1977, Methods for determination of radioactive substances in water and fluvial sediments: U.S. Geological survey Techniques of Water-Resources Investigations, Book 5, Chapter A5, 95 p.

Wanty, R.B., and Schoen, Robert, 1991, A review of the chemical processes affecting the mobility of radionuclides in natural waters, with applications, in Gundersen, L.C.S., and Wanty, R.B., eds., Field studies of radon in rocks, soils, and water: U.S. Geological Survey Bulletin 1971, p. 183-194. 